\title{
As aventuras de Nhô Quim: o marco histórico dos
}

\section{quadrinhos no mundo}

\section{The adventures of Nhô Quim: the historic landmark of comics in the world}

10.11606/2316-9877.2021.v9i2.153373

\section{André Luis Soares Smarra ${ }^{1}$}

Universidade Estácio de Sá

Cesar Augusto Lotufo ${ }^{2}$

Centro Universitário Augusto Motta

Luciano Filizola da Silva ${ }^{3}$

Centro Universitário Augusto Motta

Nataniel dos Santos Gomes ${ }^{4}$

Universidade Estadual de Mato Grosso do Sul

\footnotetext{
${ }^{1}$ Graduado em Ciências Biológicas pela Universidade Estadual Paulista Júlio de Mesquita Filho - UNESP (Bacharelado - 1994 e Licenciatura - 1996). Especialista em Bioquímica (2007), Fisiologia Humana (2007), Educação Ambiental (2014) e Gestão Ambiental (2014) todas pelo Conselho Regional de Biologia - CRBio. Mestre em Física (1997) também pela Universidade Estadual Paulista Júlio de Mesquita Filho - UNESP. Email: andre@smarra.com.br. https://orcid.org/0000-0003-2900-768X.

2 Graduado em Arqueologia pela Universidade Estácio de Sá (1983) e mestrado em Geografia pela Universidade Federal do Rio de Janeiro (1991). Tem experiência nas áreas de Arqueologia e Meio Ambiente, atuando principalmente nos seguintes temas: Rio de Janeiro, Culturas Tradicionais, Histórias em Quadrinhos, Responsabilidade socioambiental e Gestão Ambiental. lotufocesar@gmail.com. (D) https://orcid.org/0000-0002-5465-5788.

${ }^{3}$ Graduado em Direito pela Universidade Candido Mendes (1999) e mestrado em Ciências Criminais pela Universidade Candido Mendes (2003). Atualmente é prestador de serviço da Escola da Magistratura do Estado do Rio de Janeiro e professor auxiliar I da Faculdade Signoreli. Email: lucianofilizola1976@gmail.com. (D) https://orcid.org/0000-0001-6026-2131.

${ }^{4}$ Graduado em Letras (Português/Literatura) pela Universidade do Estado do Rio de Janeiro (1996). Mestrado em Linguística pela Universidade Federal do Rio de Janeiro (2002). Doutorado em Linguística pela Universidade Federal do Rio de Janeiro (2007). Pós-Doutor em Língua Portuguesa na Universidade do Estado do Rio de Janeiro (UERJ). Professor da graduação e do programa de pós-graduação (Mestrado Acadêmico em Letras e Mestrado Profissional em Letras) da Universidade Estadual de Mato Grosso do Sul (UEMS), unidade de Campo Grande. Email: natanielgomes@uol.com.br. (D) https://orcid.org/0000-0003-3911-1552.
} 


\section{Resumo}

Visa estabelecer um marco teórico quanto à definição de histórias em quadrinhos como um segmento artístico e cultural, bem como um marco histórico, desenvolvendo um contraponto a respeito da discussão sobre qual seria a primeira história em quadrinho publicada no mundo. Ainda que, de maneira predominante, atribuam tal feito a Outcault com seu Yellow Kid em 1896, busca-se demonstrar que a primeira obra publicada desse gênero foi As aventuras de Nhô Quim de Angelo Agostini, publicada no Brasil, mais precisamente na revista Vida Fluminense, em 30 de janeiro de 1869, ou seja, 27 anos antes.

Palavras-Chave: Histórias em quadrinhos. Primeira história em quadrinhos. Nhô Quim (Personagem). Origem das histórias em quadrinhos.

\section{Abstract}

Aims to establish a theoretical framework regarding the definition of comics, as an artistic and cultural segment, as well as a historical framework, developing a counterpoint regarding the discussion about which would be the first comics published in the world. Although, in a predominant way, this feat is attributed to Outcault with his Yellow Kid in 1896, it will try to demonstrate that the first published work of this genre was The adventures of Nhô Quim, by Angelo Agostini, published in Brazil, more precisely in the magazine Vida Fluminense, on January 30, 1869, that is, 27 years earlier.

Keywords: Comics. First Comics. Nhô Quim (Character). Origin of Comics.

\section{Introdução}

As histórias em quadrinhos têm conquistando cada vez mais espaço em escolas, nas bibliotecas, nas residências, na mídia e nas universidades. Há muita discussão sobre o surgimento dos quadrinhos, mas uma das teorias mais aceitas reconhece seu surgimento nos Estados Unidos, no final do século XIX, configurando um tripé para a comunicação de massa: quadrinhos, jornais e cinema.

Desde um passado remoto, as representações em forma de desenhos já estavam presentes para que o ser humano as usasse para perpetuar uma informação, uma história ou mesmo para comunicar algo. Os desenhos encontrados em rochas e em cavernas (tanto no Brasil quanto na Europa) revelam essa necessidade de contar histórias por meio de imagens e deixá-las eternizadas. Desenhos e imagens são usados até hoje para reproduzir o trajeto dos homens santos nas paredes e tetos das igrejas. 
Vergueiro comenta que os quadrinhos nem sempre tiveram o devido reconhecimento:

Durante boa parte do século $\mathrm{XX}$, as histórias em quadrinhos sofreram rejeição quase que generalizada por parte da sociedade, sendo alvo de preconceitos, perseguições e medidas judiciais que visavam conter ou erradicar da face da Terra qualquer produto quadrinístico. (2010, p. 6)

Apesar de todo o preconceito, surgiram defensores das histórias em quadrinhos, que começaram a estudar o fenômeno em escolas e universidades, mesmo com o risco do estigma de seus pares. Sobre isso, Cagnin (2013, p.11) comenta:

\begin{abstract}
Valorizados estão os quadrinhos, por terem assumido com tanto entusiasmo pelo empertigado e sisudo meio acadêmico, que até então Ihes devotava cuidadoso distanciamento para não ver maculado - como julgavam - o conceito de ilustres intelectuais, nem desviar-lhes o interesse para tema tão trivial de criança. Valorizada está a própria universidade ao se voltar para eles, redimensionando a eficácia, a penetração desse nosso meio de comunicação e a sua riqueza enquanto arte e sistema de significação.
\end{abstract}

As histórias em quadrinhos proporcionam ao leitor informação, entretenimento e orientações sobre os mais variados assuntos (trânsito, saúde, economia, biografia, acessibilidade etc) de forma leve e direita, além de ensinamentos sobre ética, moral e respeito ao próximo. Por terem grande circulação, várias premissas ideológicas foram disseminadas ao longo da história, principalmente com relação às suas origens.

The Yellow Kid (1896) para muitos é a primeira história em quadrinhos produzida no mundo, o primeiro sucesso de vendas nos Estados Unidos e ao redor do mundo, criado por Richard Felton Outcault. Todavia, bem antes disso, um italiano naturalizado brasileiro, chamado Ângelo Agostini, já desenvolvia sua arte e contava suas histórias por aqui por meio de As Aventuras do Nhô Quim, que iniciou sua publicação em 30 de janeiro de 1869, com grande viés crítico à política de sua época.

Sem dúvida, outras obras colaboraram para a evoluçãos dos quadrinhos, como as do suíço Rudolf Töpffer que escreveu Histoire de Mr. Jabot, publicado em 1833; do alemão Willhelm Busch, criador de Max und Moritz, publicada em 
1865, chamados aqui no Brasil de Juca e Chico. Essas obras, porém, estavam muito mais próximas das novelas ilustradas e não possuiam ainda o ritmo e 0 modelo das atuais histórias em quadrinhos.

Entre as décadas de 1950 e 1960, os quadrinhos infantis feitas por brasileiros ganharam destaque. Os cartunistas de maior renome foram Maurício de Sousa e Ziraldo Alves Pinto. Eles conseguiram criar personagens com perfis tipicamente brasileiros que continuam a encantar gerações de leitores, no Brasil e no mundo (LOTUFO, SMARRA, 2014).

\section{1 - As histórias em quadrinhos}

Cagnin (1975, p.19) afirma que "O homem tem marcada tendência para contar, ouvir, ver ou ler histórias. É uma constante universal no tempo e no espaço: em todas as épocas temos narrativas, em todos os lugares habitados há histórias." Talvez isso explique o sucesso para as narrativas com imagens, como as histórias em quadrinhos. Sem levar em conta que o acesso à leitura tipográfica ainda não é domínio de toda a população mundial, mesmo que a situação de acesso já tenha sido muito pior. Assim, uma forma de perpetuar a informação era por meio de imagens. Além disso, modernamente, a sociedade tem se tornado cada vez mais visual. Basta observar as antigas propagandas antigas em revistas com as atuais. Há cada vez menos elementos tipográficos e mais visuais. Nesse sentido, a leitura mudou e se tornou mais visual.

Não é uma tarefa fácil determinar o surgimento dos quadrinhos e depende da definição utilizada. Assim, se eles forem considerados como a arte de narrar histórias por meio de desenhos, as pinturas nas cavernas da Idade das Pedras, podem ser consideradas como precursoras; no entanto, se, ao contrário, definirmos que os quadrinhos surgem a partir dos balões de fala, sua origem remonta ao século XIX.

Rahde (1996, p. 104) lembra que

[...] a história em quadrinhos atual possui mais um elemento gráfico na sua composição, que aparece como um prolongamento do personagem, o que proporciona maior dinamização na leitura: são os chamados balões. 
A opção deste trabalho é que as histórias em quadrinhos são narrativas de textos sequenciais unidas a imagens com ou sem balões, demarcadas pelo uso de quadros. Como foi dito na introdução, o uso de desenhos para perpetuar narrativas é uma prática antiga. Tal prática servia para registrar festas, lutas, caças e o cotidiano, conforme os registros encontrados em cavernas de Lascaux e Chauvet, na França, de Altamira, na Espanha, de Tassili, na região do Saara, na África, e as do município de São Raimundo Nonato, Piauí, no Brasil. (PROENÇA, 2005, p.6 apud SILVA, 2015). Tais desenhos não podem ser considerados quadrinhos, de acordo com a definição escolhida porque apresentam delimitações de quadros, e são tão somente registros visuais de eventos que foram eternizados por meio de imagens.

[...] O homem primitivo, por exemplo, transformou a parede das cavernas em um grande mural, em que registrava os elementos de comunicação para seus contemporâneos: o relato de uma caçada bem sucedida, [...] Assim quando o homem das cavernas gravava duas imagens, uma dele mesmo, sozinho, e outra incluindo um animal abatido, poderia estar, na realidade, vangloriando-se por uma caçada vitoriosa, mas também registrando a primeira história contada por uma sucessão de imagens. Bastaria, então, enquadrá-las para se obter algo muito semelhante ao que modernamente se conhece como história em quadrinhos. [...] (VERGUEIRO, 2004, p. 8 e 9)

Assim como apresentado na introdução, para grande parte dos pesquisadores, as histórias em quadrinhos surgiram nos Estados Unidos, no final do século XIX. Elas representavam uma maneira inovadora de comunicação em massa, graças ao desenvolvimento da tipografia e a proliferação de jornais naquele país, foi possível sua criação e popularização. As vantagens dos Estados Unidos para o surgimento dos quadrinhos estavam ligadas à tecnologia, à economia, além do interesse do público por um suporte mais imagético, o surgimento do cinema (que desde o início alimentou os quadrinhos e vice-versa). Para Vergueiro:

Ainda que histórias ou narrativas gráficas, contendo os principais elementos da linguagem dos quadrinhos possam ser encontradas, paralelamente, em várias regiões do mundo, é possível afirmar que o ambiente mais propício para seu florescimento localizou-se nos Estados Unidos do final do século XIX, quando todos os elementos tecnológicos e sociais encontravam-se devidamente consolidados para que as histórias em quadrinhos se transformassem em um 
produto de consumo massivo, como de fato ocorreu. (VERGUEIRO, 2004, p.10)

A concretização do cinema em 1885 pelos irmãos Lumière ajudou no processo de evolução das histórias em quadrinhos. Inicialmente o cinematógrafo projetava fotografias de forma sucessiva para dar sensação de movimento. (BRASIL, 2008, p. 87).

Richard Felton Outcault, considerado por muitos o criador do atual modelo das histórias em quadrinhos, nasceu em Ohio em 14 de janeiro de 1863 e começou sua carreira como desenhista técnico de Thomas Edison. Mas, indo para o New York Journal ele criou as histórias de seu mais conhecido personagem, o Yellow Kid, em 1896.

Porém, segundo Cagnin (1997, p.25), The Yellow Kid (1896, figura 1) não é a primeira história em quadrinhos produzida na História, mas o primeiro sucesso de vendas nos Estados Unidos e ao redor do mundo. Outcault conseguiu que seu The Yellow Kid se transformasse em um fenômeno nos jornais de Nova York, por isso, conseguiu o posto de criador da primeira narrativa quadrinizada. Na verdade, esse autor fez alguns avanços em relação ao trabalho de outros artistas, introduzindo um elemento visual: o balão de fala. Mas, ainda assim, de forma tímida, pois em várias histórias utilizou-se do texto corrido ou com as falas estampadas na camisola do personagem. De qualquer forma, o sucesso foi tanto que os jornais novaiorquinos passaram a disputar suas tiras.

Figura 1: The Yellow Kid
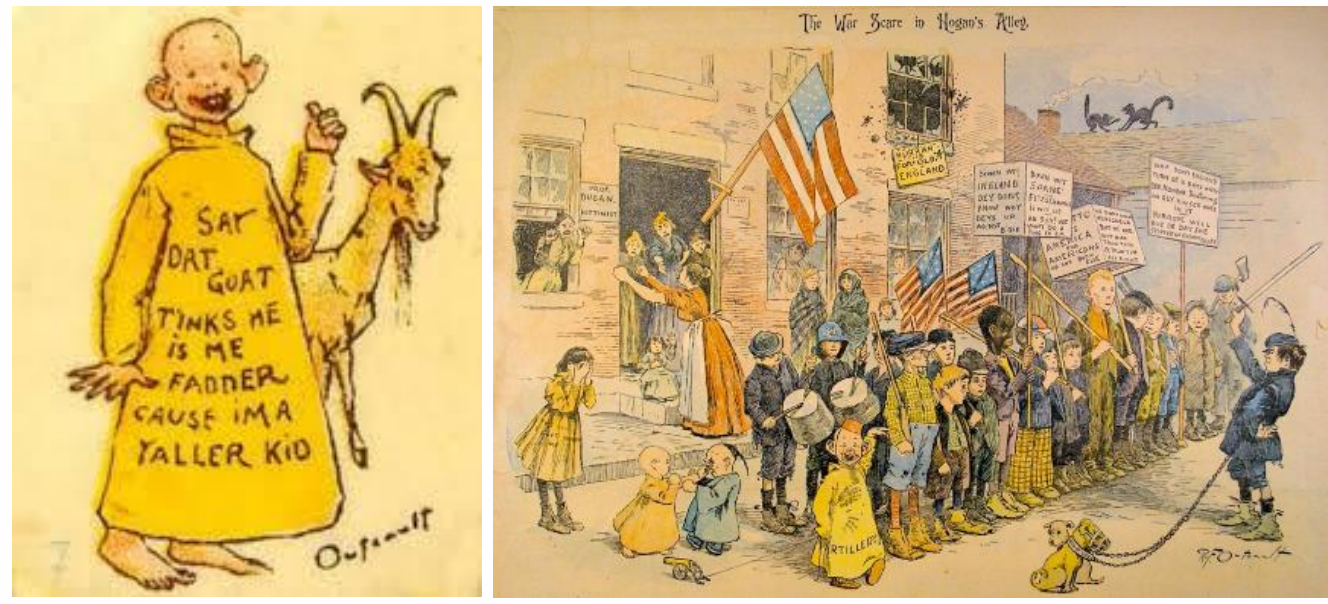

Fonte: Disponível na internet:

https://kingydesignhistory2012.files.wordpress.com/2012/04/1687203yellow kid $1896 \quad 3$ 15.jpg. Acesso em 12 de outubro de 2016, às 20h05m 
Conforme Couperie et al. (1970, p. 9).

Aos poucos, a imagem adaptou-se aos textos, especialmente durante o século XX, quando as tiras ganharam "vida", uma vez que a técnica passou a exercer uma importante função de comunicação, a partir da junção da imagem com o texto.

As histórias em quadrinhos têm vários nomes pelo mundo: comics, em países de língua inglesa; mangás, no Japão; fummetti, na Itália; e gibi, no Brasil. Passaram a ser produzidas em grande escala, tratando dos mais diversos assuntos, sempre se renovando e passando a ser vista como um fator de propulsão no consumo.

Assim, as histórias em quadrinhos, além de serem um dos primeiros veículos a caminhar para a padronização de conteúdos, também incorporavam a globalização econômica em seus processos de produção, garantindo, dessa forma, a sobrevivência em um mercado cada vez mais competitivo. (VERGUEIRO, 2004, p. 7).

Estando o surgimento dos quadrinhos ligado à origem do cinema e da popularização dos jornais, um retroalimentando o outro, desde sua origem, basta olhar a lista de maiores sucessos de bilheteria no cinema e se notará que uma parte considerável dos filmes tem origem em narrativas dos quadrinhos. Apesar disso, elas eram consideradas como influências negativas para crianças e adolescentes, já que não tratavam de temas ligados à narrativa tradicional, principalmente por utilizar imagens. Por esses e outros motivos, foram classificadas como pertencentes a um submundo cultural até os anos 1960, quando começaram a surgir os primeiros admiradores entre professores e pesquisadores.

\subsection{As histórias em quadrinhos no Brasil}

O surgimento das histórias em quadrinhos em terras brasilis se deu por meio de Ângelo Agostini, um italiano que morava em nosso país. Ele era jornalista, além de ser crítico da monarquia e ferrenho defensor da abolição da escravatura. Em 1869, ele publicou As Aventuras de Nhô Quim, na revista Vida Fluminense. (CALAZANS, 1997, p.5) 
Figura 2: As aventuras de Nhô Quim

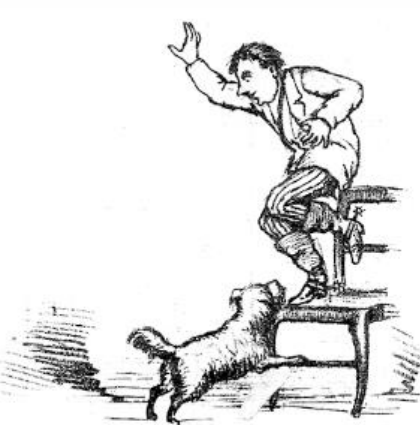

Procurou um refúgio, mas vendo que nem assim se livrava da sanha do diabo do totó,
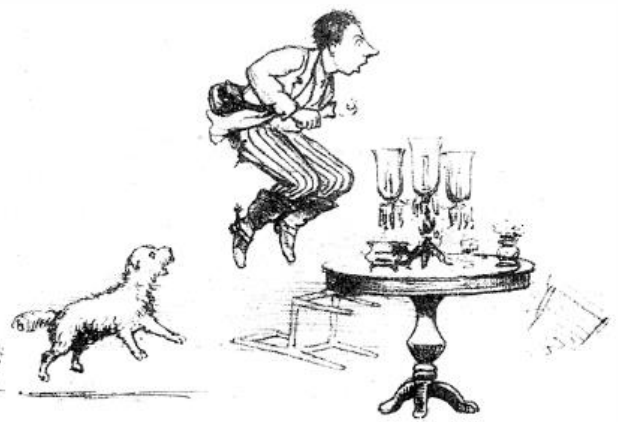

pulou sobre a mesa, pondo tudo em estilhaços.

Fonte: Disponível na internet: https://quadrinhos.files.wordpress.com/2011/07/06-nhoquimcao.jpg Acesso em 12 de outubro de 2016, às 21h07m

Para Cagnin (1997), As Aventuras de Nhô Quim é a primeira história em quadrinhos do mundo. A questão é que ela não conseguiu tal reconhecimento e ainda há divergências se tal informação é verdadeira. Segundo Bari, para efeito de internacionalização, o primeiro registro mundial fica com The Yellow Kid, de Richard Felton Outcault, publicada em 1895 (MOYA, 2003, p.95 apud BARI, 2008, p. 44).

Para Mutarelli (2004, p. 22 apud BARI, 2008), existe uma polêmica em relação ao primeiro personagem dos quadrinhos:

\begin{abstract}
Existe uma controvérsia entre os pesquisadores da área sobre o primeiro personagem, o marco inicial dessa linguagem que marcou o século XX, Yellow Kid, que foi publicada pela primeira vez no jornal norte-americano New York World em 05 de maio de 1895 , foi o primeiro a aproximar o texto do personagem e a utilizar balões de falas e pensamentos. [...] No entanto, entre os precursores da Nona Arte [...] temos [anteriormente] o suíço Rudolf Töpffer, [...] o alemão Willhelm, Busch [...], o francês Georges Colomb [...], e o italiano Ângelo Agostini.
\end{abstract}

O que se entende é que Agostini produziu a história em quadrinhos, mas que esta não foi divulgada devidamente para o público, na época, como tal. Por isso, o título da primeira publicação da Nona Arte ficou para The Yellow Kid.

Agostini morou em diversas cidades brasileiras, ensinou sua arte para muitos e publicou em 1864 O Diabo Coxo, seu primeiro periódico ilustrado e o jornal humorítisco, O Cabrião, que circulou por 12 meses de forma ineterrupta. 
No Rio de Janeiro, centro de publicações periódicas, Agostini colaborou com diversos jornais. Em 1876, fundou A Revista llustrada. Mas antes, em 1869, publicou o folhetim Nhô-Quim ou Impressões de Uma Viagem à Corte, publicada 26 anos antes de The Yellow Kid. O formato adotado por Agostini é bastante similar às graphic novels modernas.

Em 1895, Agostini criou a revista Dom Quixote. Em 1904, escrevia para a revista $O$ Malho e no ano seguinte, foi um dos fundadores da revista O Tico-Tico, publicação que fugiu da sátira política e marcou início dos quadrinhos para crianças em processo de alfabetização. A publicação durou mais de 50 anos.

A partir da Proclamação da República rompeu-se o vínculo político entre Brasil e Portugal, o que redirecionou a nossa influência cultural, sobretudo na imprensa, gerando novas propostas estéticas por parte dos brasileiros. Nos anos de 1910, as sátiras políticas estavam em seu ápice.

Após a Proclamação da República, no Rio de Janeiro, o sanitarista Oswaldo Cruz lutou no combate às doenças edêmicas e epidêmicas; em parte como reação à severidade e ao autoritarismo, começou a Revolta da Vacina (1904). É nesse momento que surgem as mais variadas charges a partir de artistas desconhecidos, o que ainda alavancou os periódicos cariocas (figura 3).

Figura 3: Charge sobre a Revolta da Vacina

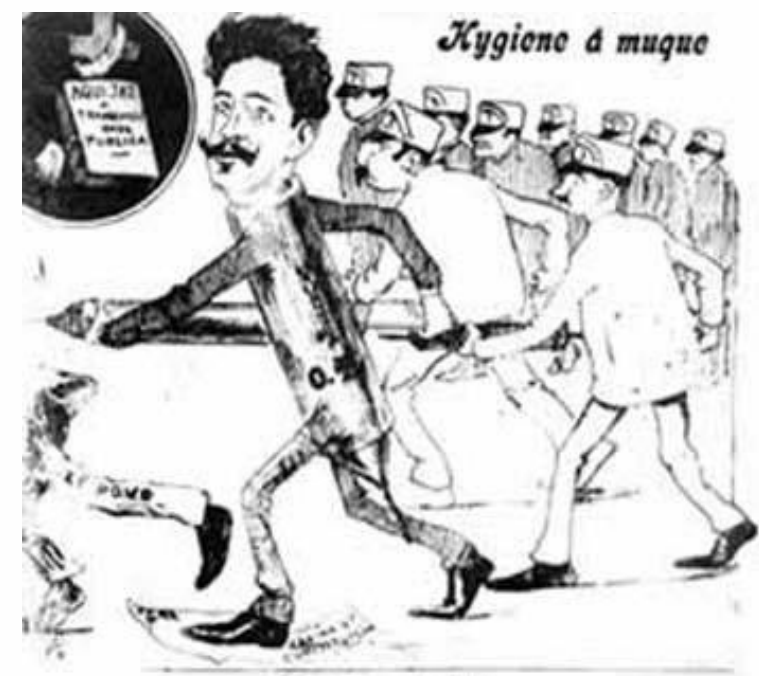

Fonte: Disponível na internet:

http://2.bp.blogspot.com/kvcNzN TaXw/T949jm0WcDI/AAAAAAAALXE/2116GxUACvM/s1600/r evolta+vacina4.jpg. Acesso em 12 de outubro de 2016, às 22:32. 
A Semana da Arte Moderna catapultou a produção artística brasileira, sem deixar de lado as histórias em quadrinhos. Nesse contexto, Nair de Teffé Hermes Fonseca se consagra como artista gráfica. Ela era filha de barão e esposa de presidente da república, por isso utilizou o o pseudônimo, Rian, para não ter seu nome associado a uma arte considerada "menor". Seus desenhos eram publicados pela revista Fon Fon, dando oportunidade não somente para ela, mas paravários outros artistas gráficos.

Durante o chamado Estado Novo houve a regulamentação de diversas atividades em nosso país. As charges políticas foram perseguidas, surgindo a oportunidade para que as obras infanto-juvenis ganhassem maior destaque nas editoras. Destacaram-se Adolfo Aizen com Suplemento Juvenil e Roberto Marinho com O Globo Juvenil.

(...) o Estado Novo tinha uma marca fundamental: a ambiguidade com a demarcação de um Estado autoritário, assinalando um período de grande modernização econômica e social, o que é evidenciado pelo avanço da industrialização e urbanização, pela crescente racionalização do aparelho burocrático do Estado e pela implementação de políticas sociais que abarcaram, entre outras, as áreas da regulamentação das relações de trabalho, da saúde pública, da educação e também da cultura, em sentido mais amplo. (GOMES, 2010)

Entre as décadas 1950 e 1960, os quadrinhos nacionais ganharam um grande impulso. Maurício de Sousa e Ziraldo criaram personagens atemporais, tipicamente brasileiros, que marcaram gerações de leitores.

Em 1954, Mauricio de Sousa criou os personagens Bidu e Franjinha para suplementos de jornais de São Paulo. Em 1961, ele criou o personagem rural Chico Bento, um coadjuvante das histórias de Hiroshi e Zezinho, cujo sucesso levou à criação de uma publicação própria, em 1982. Em 1963, o cartunista, inspirado em suas filhas, criou as personagens Mônica e Magali. Dai em diante, ele continuou criando personagens, ao ponto de suas revistas atingirem o topo das vendas de quadrinhos no país, batendo Superman, Batman e Homem-Aranha.

Ziraldo produziu diversos personagens infantis que fazem parte de $A$ Turma do Pererê, além da Super-Mãe e de O Mineirinho. Assim como Mauricio de Sousa, sua produção foi levada para o cinema, para desenhos animados, além de séries de TV (VERGUEIRO, 1985) 


\title{
2. A linguagem das histórias em quadrinhos
}

A seguir faremos uma breve descrição da linguagem dos quadrinhos para entender como As Aventuras do Nhô Quim se utilizam de tais recursos e pode serconsiderada como a primeira história em quadrinhos publicada no mundo. .

\subsection{Narrativa}

As histórias em quadrinhos utilizam a narração unida a imagens para transmitir suas ideias, envolvendo personagens, tempo, espaço e acontecimentos organizados em sequência, numa relação de causa e efeito.

Eisner (2005, p. 19) afirma que:

\begin{abstract}
Uma "imagem" é a memória de um objeto ou experiência gravada pelo narrador fazendo uso de um meio mecânico (fotografía) ou manual (desenho). Nos quadrinhos, as imagens são, geralmente, impressionistas. Normalmente, elas são representadas de maneira simplista com o intuito de facilitar sua utilidade como linguagem. Como a experiência precede a análise, o processo digestivo intelectual é acelerado pela imagem fornecida pelos quadrinhos.
\end{abstract}

Geralmente, a linguagem verbal se manifesta por meio dos balões, das legendas, das onomatopeias e das interjeições. Já a linguagem não verbal é apresentada, entre outros, por gestos. Sem tais recursos de linguagem, as histórias em quadrinhos tornam-se ilegíveis.

As Aventuras de Nhô-Quim, de Ângelo Agostini, publicadas no jornal Vida Fluminense, em pleno século XIX, já traziam essas narrativas, conforme imagem abaixo: 
Figura 4 - Capítulo 1 de Aventuras de Nhô-Quim.

As Aventuras de "Nhô-Quim", ou impressōes de uma viagem à corte

Ángelo Agostini (30 de joneiro de 1869 - Jornol Vido Fluminense) Histório em muitos copitulos
(De Minos oo Rio de Joeneiro)

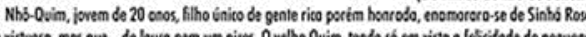

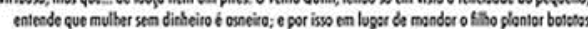

CopituloI

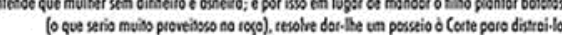
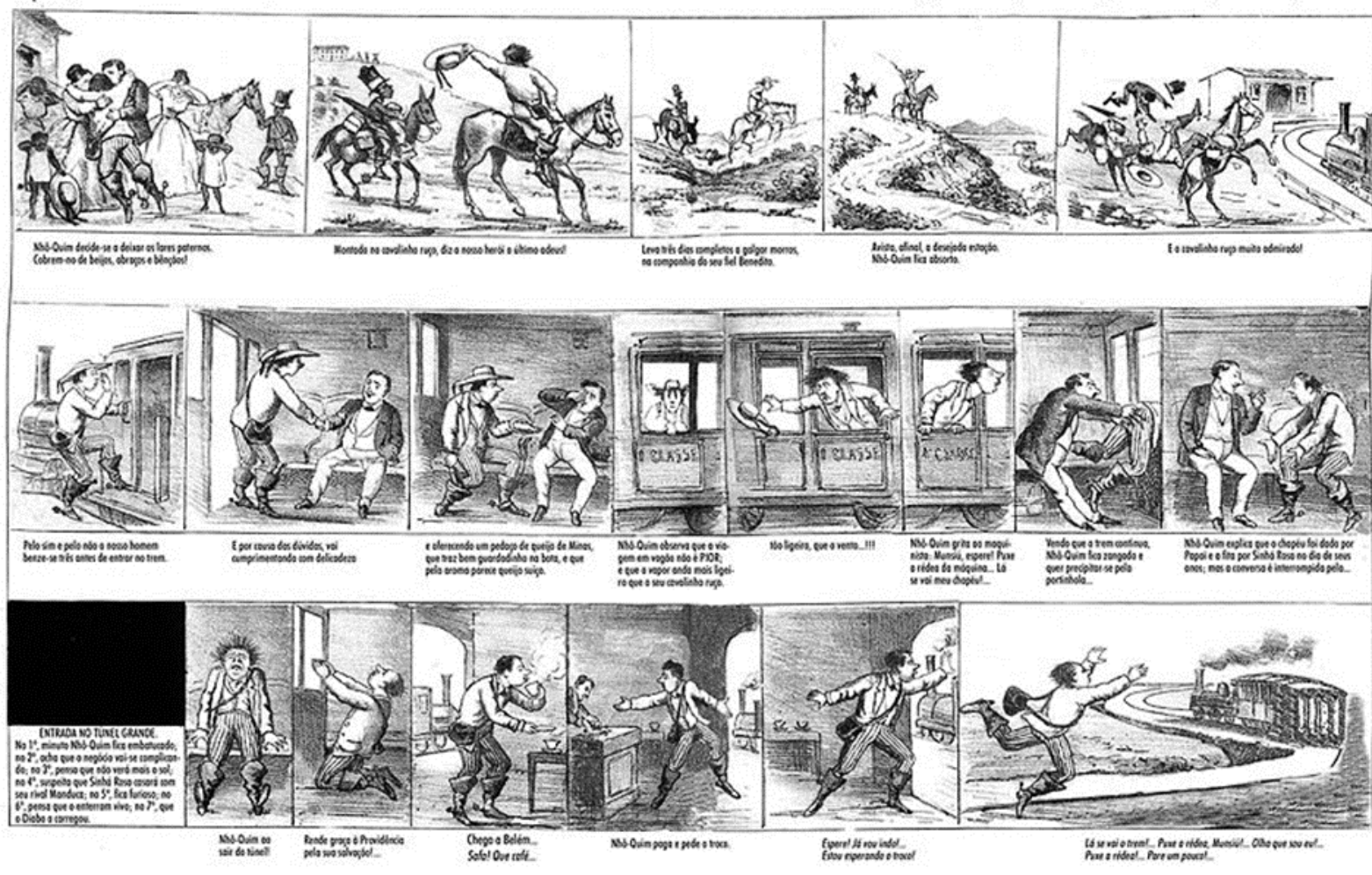

mexpoutriatureen

Fonte: Disponível na internet:

https://pt.wikipedia.org/wiki/As Aventuras de Nh\%C3\%B4 Quim ou Impress\%C3\%B5es de Uma Viagem \%C3\%A0 Corte\#/media/Ficheiro:Nh\%C3\%B4 Quim.jpg. Acesso em 15 out. 2018.

Eisner (1989, p. 8) afirma que:

A configuração geral da revista de quadrinhos apresenta uma sobreposição de palavra e imagem, e, assim, é preciso que o leitor exerça as suas habilidades interpretativas visuais e verbais. As regências da arte (por exemplo, perspectiva, simetria, pincelada) e as regências da literatura (por exemplo, gramática, enredo, sintaxe) superpõem-se mutuamente. A leitura da revista de quadrinhos é um ato de percepção estética e de esforço intelectual.

Geralmente, as histórias em quadrinhos ocidentais apresentam uma sequência de quadros que caminham da esquerda para a direita e de cima para baixo (figura 5). Para Martins (2004, p. 23): 
Quadrinhos ou histórias em quadrinhos são narrativas feitas com desenhos sequenciais, em geral no sentido horizontal, normalmente acompanhados de textos curtos, de diálogo e algumas descrições da situação, convencionalmente, apresentados no interior de figuras chamadas balões.

Alguns elementos encontrados para induzir o leitor à leitura sequencial são a presença ou não de cores, o tipo de traço, o estereótipo das figuras, a disposição da linguagem verbal nos balões, entre outros.

Figura 4: Exemplo de uma típica história em quadrinhos ocidental

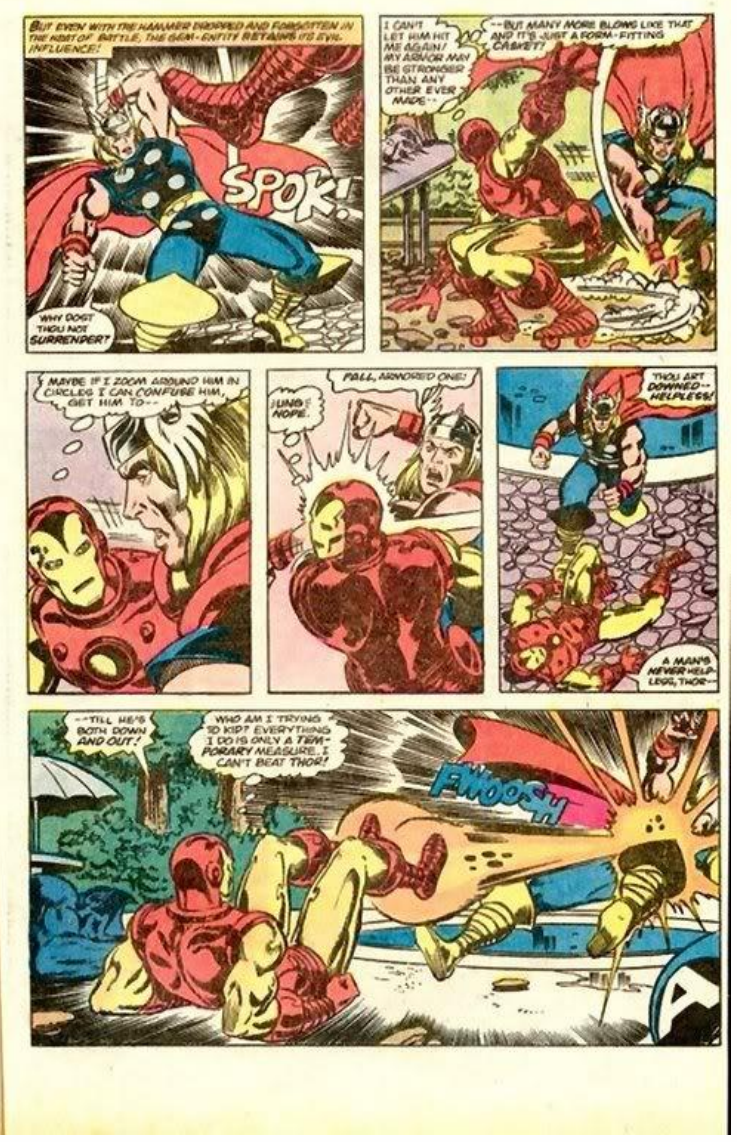

Fonte: Disponível na internet:

http://static.comicvine.com/uploads/original/6/65990/2787532-allaveng23mw.jpg. Acesso em 13 out. 2016 , às 9:00.

Uma sequência de duas ou mais imagens tende a obrigar o leitor a considerar essas imagens, como um todo, um único organismo; assim, ele passa a compreender texto e imagem conjuntamente. Para Eisner (1989), tal aplicação sistematizada cria a "gramática" da Arte Sequencial, o que Agostini faz em sua obra. 
Para Eco (2004, p. 144-150), pode-se ainda falar de "semântica e sintaxe". A primeira é ligada às relações entre os quadros e os elementos dentro deles, enquanto a segunda tem relação com a sequência narrativa das histórias (balões, leitura dos quadros, metáforas visuais, ícones, símbolos e onomatopeias).

\subsection{Linguagem verbal e não verbal}

Nas histórias em quadrinhos, um dos recursos mais importantes são os quadros. Eles são linhas que delimitam o espaço de uma determinada cena. Os quadros servem para indicar a divisão do tempo e do espaço. Ainda podem representar sons e movimentos. Com o avanço dos quadrinhos, tais linhas ganharam formatos inovadores de estilo. Sendo assim, a leitura está ligada à forma como tais quadros são posicionados na página, representando uma parte da linguagem não verbal dos quadrinhos. (EISNER,1989, p. 44)

A maioria das narrativas quadrinísticas tende à simplificação para o auxílio da leitura das imagens, o que difere dos chamados textos literários, bem mais elaborados, para que o leitor possa criar uma imagem mental da cena. Por outro lado, o desenhista usa de expressões faciais, cenários, animais, etc. para transmitir sua informação.

Figura 5: Exemplos de linguagem verbal e não verbal.

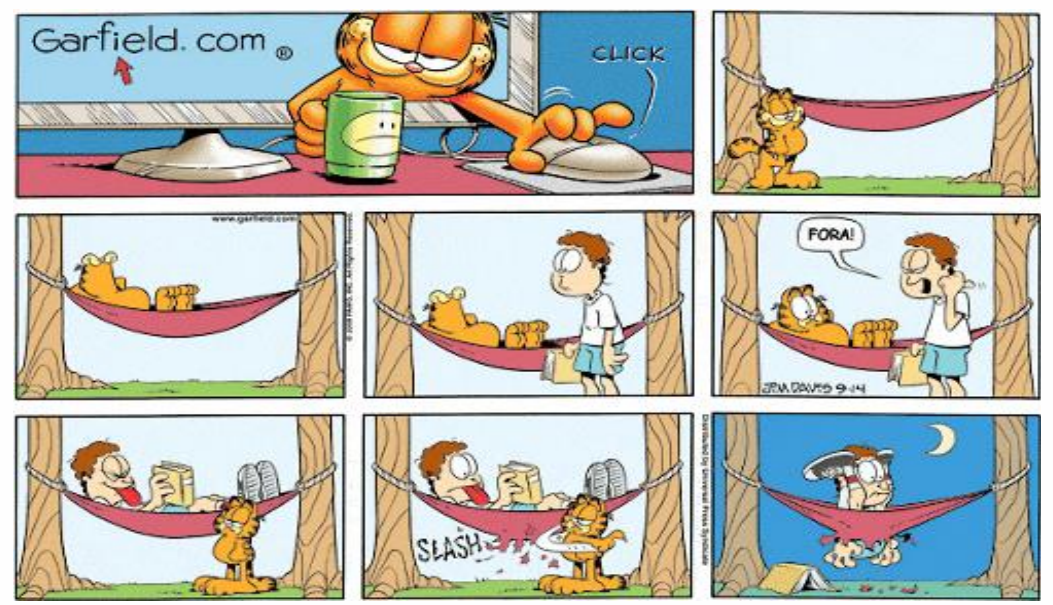

Fonte: Disponível na internet: http://s4.static.brasilescola.uol.com.br/img/2014/04/tirinha-dogarfield.jpg. Acesso em 13 out. 2016, às 10h22m.

Assim, considerando que a característica dos quadrinhos é a narrativa 
ilustrada, não se exige textos ou diálogos, desde que a sequência dos quadros seja capaz de transmitir a lógica do que está sendo narrado.

$\mathrm{Na}$ figura 7, pode-se verificar como Agostini fazia uso das expressões faciais e dos cenários em seus quadrinhos:

Figura 7: Exemplos de linguagem verbal e não verbal em Agostini

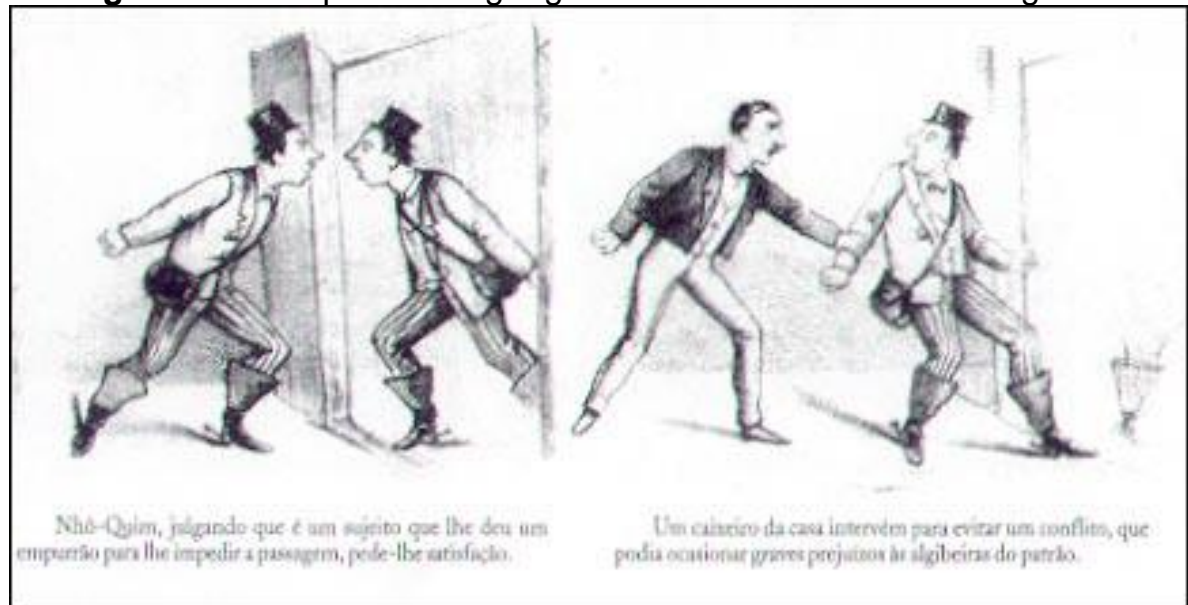

Fonte: Disponível na internet:

https://pt.wikipedia.org/wiki/As Aventuras de Nh\%C3\%B4 Quim ou Impress\%C3\%B5es de Uma Viagem \%C3\%A0 Corte\#/media/Ficheiro:Nh\%C3\%B4 Quim.jpg. Acesso em 15 out. 2018.

\subsection{Balão de texto}

Os balões de texto servem para identificar a fala dos personagens, enquadrando a fala, tornando-a visível. Eles transmitem as trocas verbais entre os personagens. Sua localização serve para indicar a sequência do diálogo.

À medida que os balões passaram a ser mais utilizados nas histórias em quadrinhos, suas características mudaram, apresentando novas formas e funções. Por outro lado, a introdução de balões tornou as histórias mais atrativas para leitor, embora eles não sejam um elemento essencial, pois, conforme citado anteriormente, não se exige texto para configurar a narrativa em quadrinhos e, com maior razão, balões, ainda que exista fala. Esse era, por exemplo, o modelo usado por Hal Foster originalmente em 1937, nas histórias do Príncipe Valente, seguido pelos artistas que deram continuidade a seu trabalho (Figura 8). 
Figura 8: Príncipe Valente, ilustrado por Harry Roland.
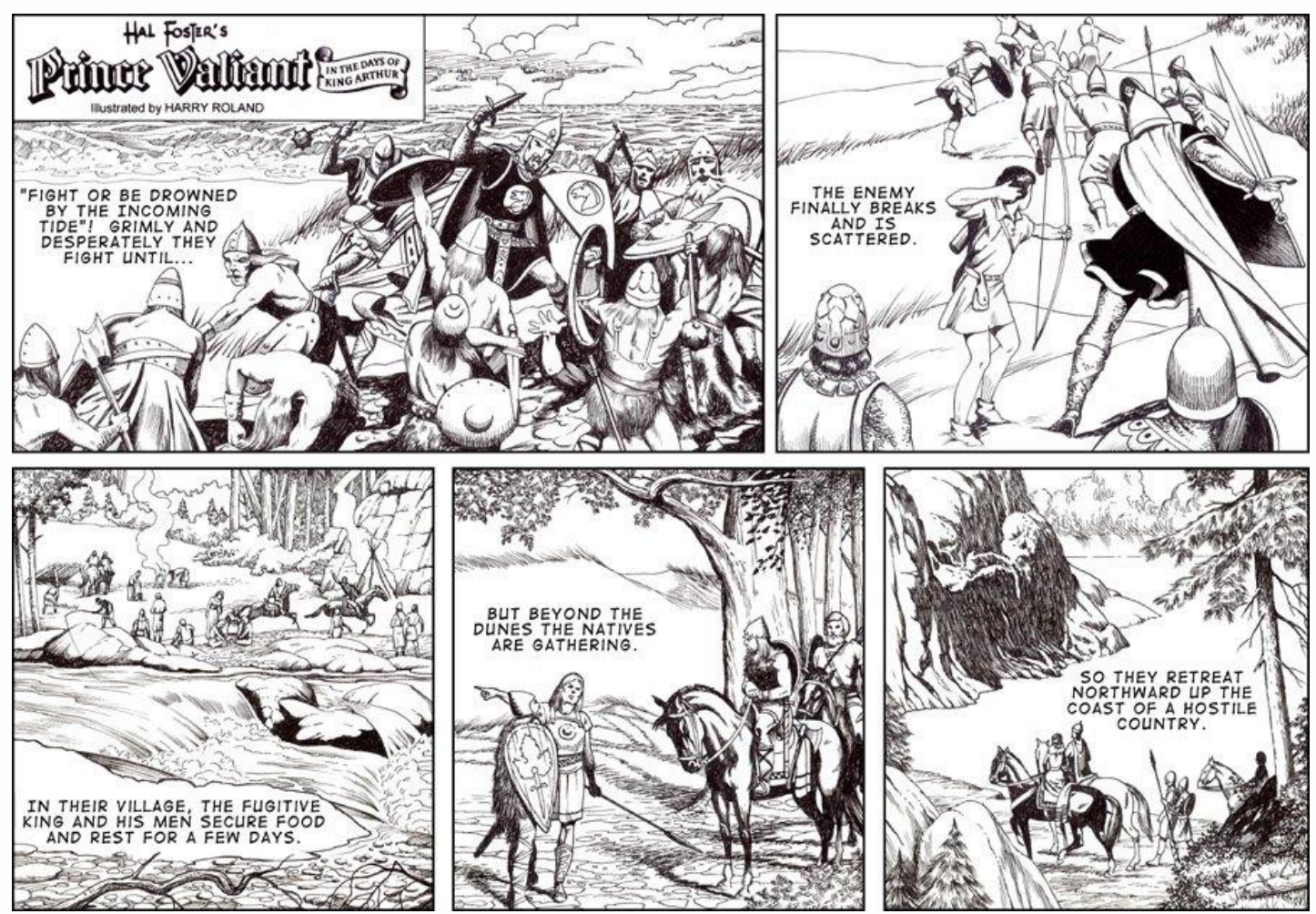

Fonte: Disponível na internet: http://www.erbzine.com/mag23/2386.html. Acesso em 14 ago. 2018 ,às $10 \mathrm{~h} 21 \mathrm{~m}$.

Com o aumento da utilização dos recursos dos balões, algumas características e funções foram se desenvolvendo e o contorno dos balões passaram a ter significados, apresentando formas diferentes e desempenhando funções e sentidos nas histórias em quadrinhos (Figura 9).

Para Ramos (2009, p. 36) existem algumas classificações para os variados tipos de balões:

Balão-fala, balão-pensamento, balão-cochicho, balão-berro, balão- trêmulo, balão-de-linhas-quebradas, balão-vibrado, balão-glacial, balão-uníssono, balões-intercalados, balão-zero ou ausência de balão, balão-mudo, balões-duplos, balãosonho, balões-especiais e balão de apêndice cortado. 
Figura 9: Alguns tipos de balões utilizados nas histórias em quadrinhos.

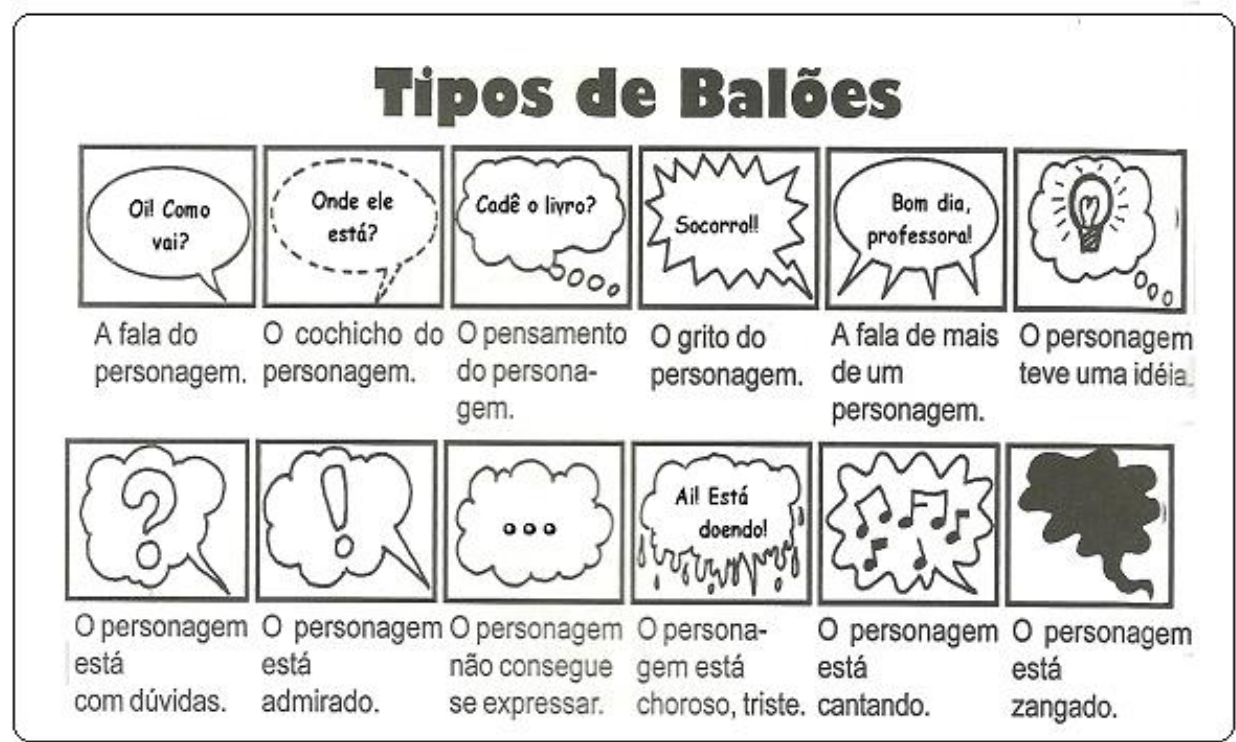

Fonte: Disponível na internet: http://www.eraumavezbrasil.com.br/wpcontent/uploads/2016/05/gui.png. Acesso em 13 out. 2016, às $10 \mathrm{~h} 34 \mathrm{~m}$.

No entanto, mesmo hoje diversos quadrinhos abrem mão de tal recurso, sem deixarem de ser uma representante da Nona Arte, não sendo um requisito indispensável, como pode ser visto na figura 9:

Figura 9: Superman: Paz na Terr (1999)

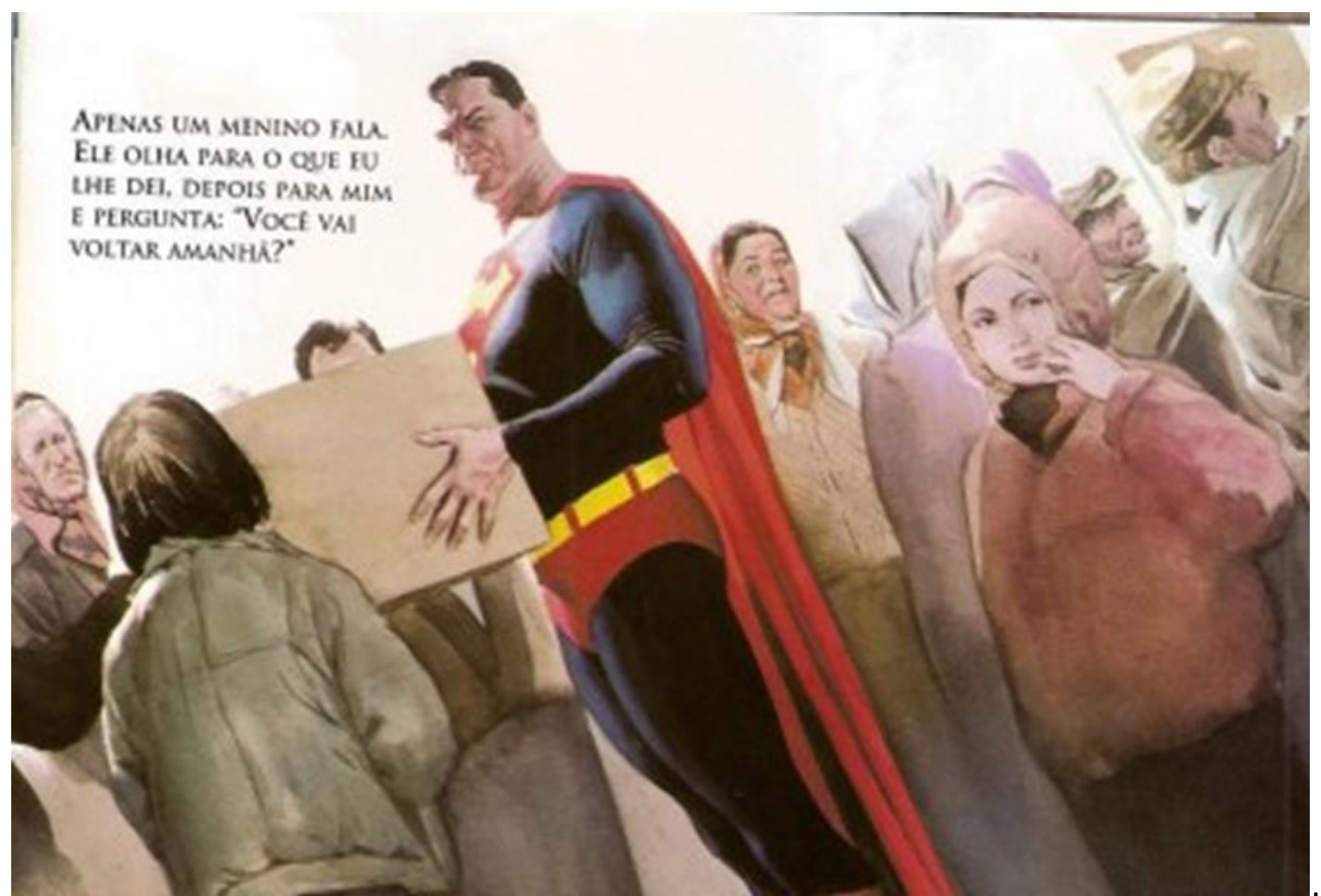

Fonte: Acervo dos autores 
Agostini não utilizou balões de fala Aventuras de Nhô-Quim, que só foram incorporados tempos depois, em Yellow Kid, não sendo um item imprescindível para caracterizar os quadrinhos.

Figura 10: As falas em Yellow Kid eram inicialmente colocadas em placas e letreiros, só posteriormente foram acrescentados os balões de fala.

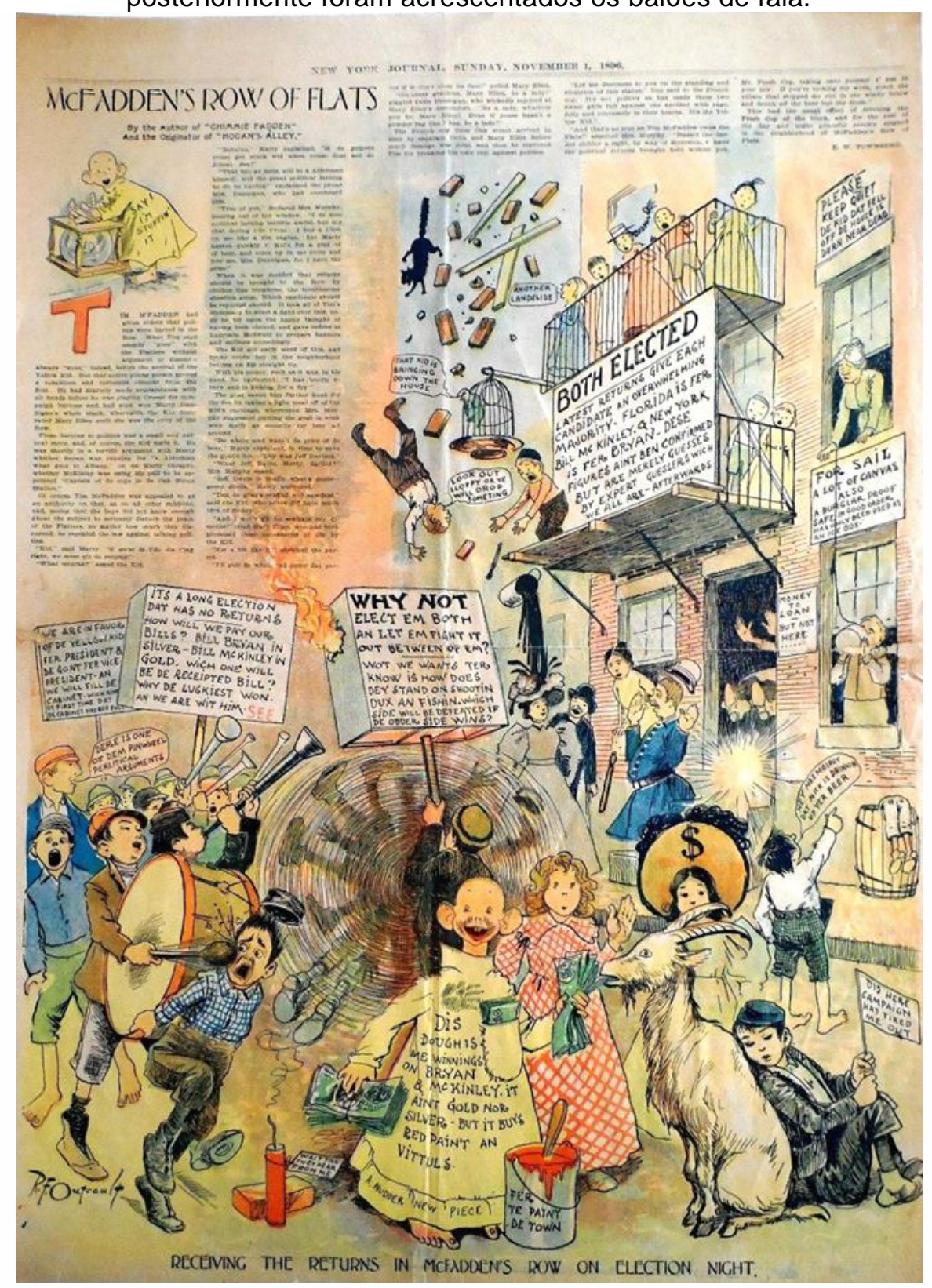

Fonte: Disponível na internet: https://nanquim.com.br/1895-yellow-kid/. Acesso em 15 out. 2018.

\subsection{Expressão anatômica}

Nas histórias em quadrinhos, a linguagem corporal dos personagens também 
desempenha um papel importante para a comunicação. Os gestos e a postura dos personagens são significativos na comunicação.

Para Eisner (1989, p. 103),

Nas histórias em quadrinhos, a postura do corpo e o gesto têm primazia sobre o texto. A maneira como são empregadas essas imagens modifica e define o significado que se pretende dar às palavras. Por meio da sua relevância para a experiência do leitor, podem invocar uma nuance de emoção e dar inflexão audível à voz do falante.

A anatomia expressiva busca reforçar informações sobre os personagens, deixando a mensagem clara. A partir dela e unida a outros elementos cenográficos, geram-se várias possibilidades de leituras. Os elementos que constituem a expressão anatômica são: o corpo, o gesto, o rosto, estrutura facial e a postura. Sendo que o rosto e a estrutura facial são as partes mais elaboradas nas histórias em quadrinhos. Ali estão concentradas as emoções. A combinação da linguagem verbal com a expressão anatômica, ajuda o leitor a identificar as características dos personagens (figura 11).

Figura 11: Esboço de expressões anatômicas.

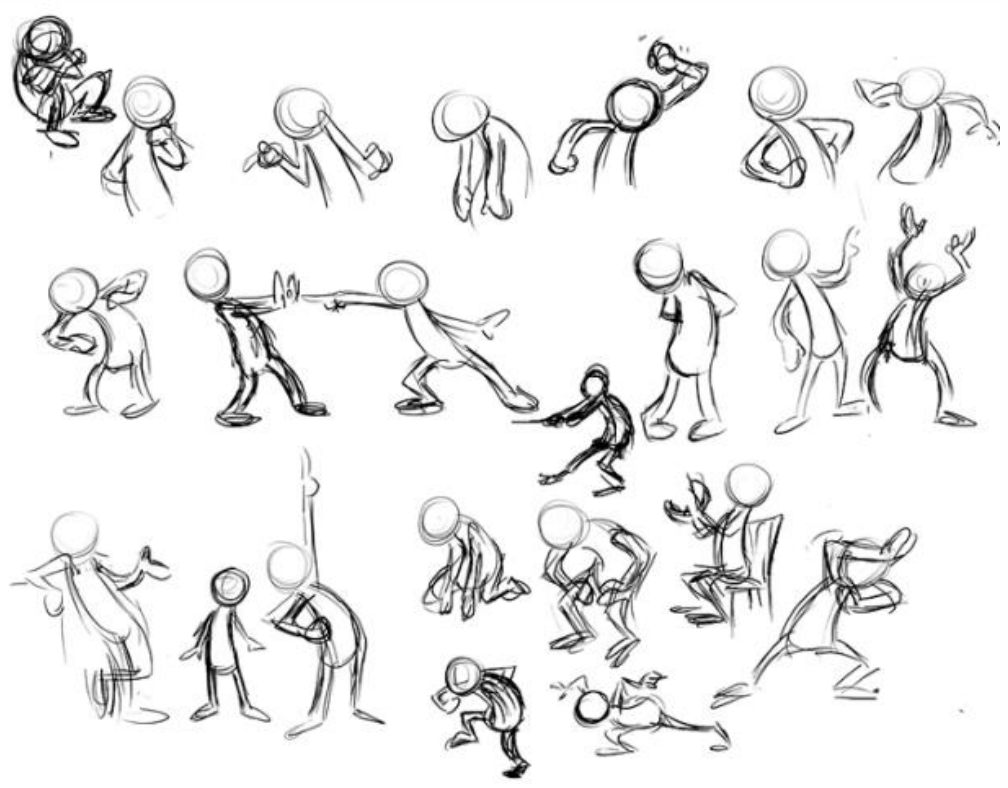

Fonte: Disponível na internet:

https://albertopessoa.files.wordpress.com/2015/09/expressive drawings.jpg Acesso em 13 out. 2016, às $10 \mathrm{~h} 47 \mathrm{~m}$.

A anatomia como forma de expressão ajuda na forma de comunicação como o rosto, os gestos e a postura desenhados por Agostini, unindo o verbal 
e a anatomia, para comunicar suas intenções enquanto artista, conforme pode ser visto na figura 12 :

Figura 12: Expressões física feitas por Agostini em sua obra.
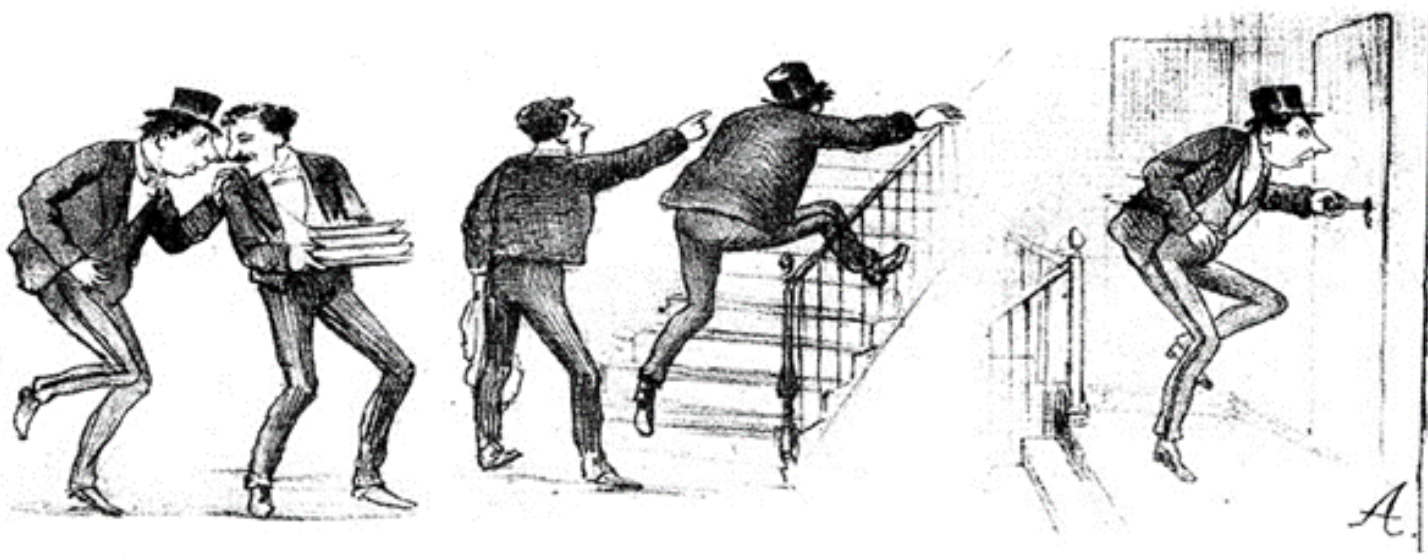

Fonte: Disponível na internet:

https://pt.wikipedia.org/wiki/As Aventuras de Nh\%C3\%B4 Quim ou Impress\%C3\%B5es de Uma Viagem \%C3\%A0 Corte\#/media/Ficheiro:Nh\%C3\%B4 Quim.jpg. Acesso em 15 out. 2018.

\subsection{Cenografia}

A cenografia está presente nas histórias em quadrinhos e faz parte da comunicação não verbal. O zoom, o close, demonstram tensão nas narrativas e constroem um impacto emocional dos personagens; por outro lado, a cenografia ajuda a transmitir o impacto emocional em relação ao leitor.

Para McCloud (2008, p. 158), "Representar todas as vistas e sensações em pequenos retângulos pode ser um desafio intimidador. (...) mas para seus leitores isso pode ser a diferença entre saber onde sua história acontece e estar lá."

A cenografia serve como um tipo de moldura, enriquecendo a história, mostrando diversos planos. Ela é constituída pela sobreposição, pelo tamanho, pela cor, pela tonalidade, pela composição e pela perspectiva.

O splash (metaquadrinho) é um tipo de página que utiliza toda a sua extensão com um único quadro, realizando uma visão panorâmica. Uma forma variante é a chamada página dupla figura 12). Nela duas páginas formam uma imagem, como se fosse pôster com narração.

Eisner (2010) lembra ainda que quadrinho de página inteira tem a 
decomposição do episódio em partes de página como tarefa essencial.

Figura 13: Exemplo de página dupla.

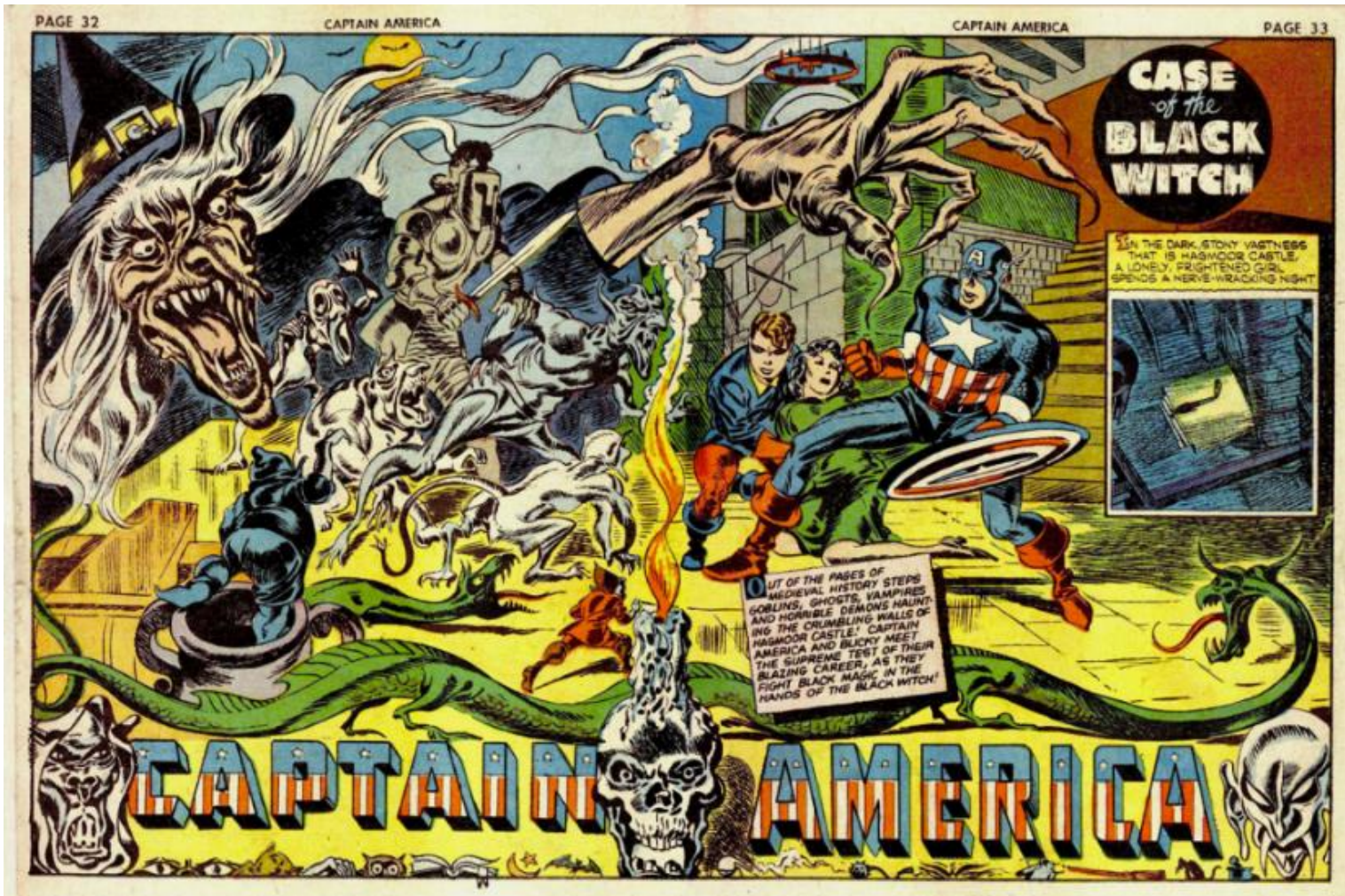

Fonte: Disponível na internet: http://kirbymuseum.org/blogs/kinetics/wpcontent/uploads/sites/11/2013/07/Kirb-Kin-Black-Witch-12.jpg. Acesso em 13 out. 2016, às $12 \mathrm{~h} 07 \mathrm{~m}$.

Para Eisner (1989, p. 23) o cenário é mais do que uma simples decoração, ele faz parte da narração. Sem a cenografia, a compreensão da história em quadrinhos fica prejudicada. Sua principal função é apresentar o personagem e sua ambientação, tornando as emoções mais atenuadas, estruturando e intensificando as emoções dos personagens, além das intenções e do desenvolvimento da arte sequencial. (Figuras 14 e 15) 
Figuras 14 e 15: Exemplos de cenografia em Agostini

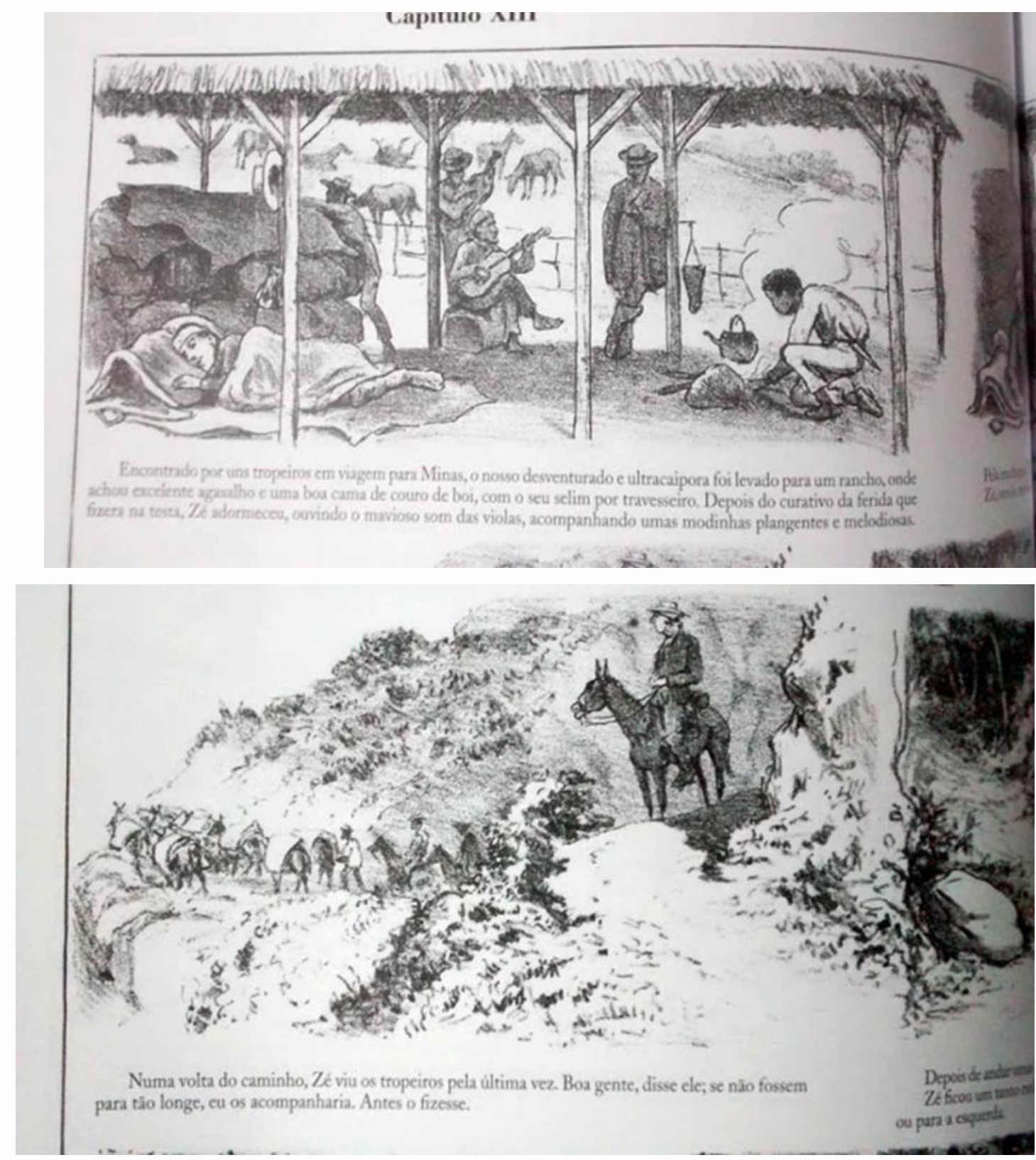

Fonte: Disponível na internet:

https://pt.wikipedia.org/wiki/As Aventuras de Nh\%C3\%B4 Quim ou Impress\%C3\%B5es de Uma Viagem \%C3\%A0 Corte\#/media/Ficheiro:Nh\%C3\%B4 Quim.jpg. Acesso em 15 out. 2018.

\subsection{Cores}

As cores estão ligadas à linguagem não verbal. Elas podem transmitir emoções vividas pelos personagens. Geralmente, a vermelha está associada à fúria. Cores opacas em determinados personagens os caracterizam com ares de negatividade.

Para Samara (2010, p. 83): 
Há poucos estímulos visuais tão potentes como as cores; elas são uma ferramenta de comunicação extremamente útil. No entanto, o significado transmitido pelas cores, por resultar da reflexão de ondas de luz transmitidas pelos olhos para 0 cérebro, é algo subjetivo.

As cores estimulam as mais variadas sensações e definem paisagens, alimentos, animais, clima, sentimentos, personalidade etc.

Aqui encontramos uma diferença em relação à obra de Richard Felton Outcault, Yellow Kid. Enquanto Agostini não utilizava cores, Outcault pode até nomear seu personagem com o nome de uma cor e usar a mesma para o seu roupão característico, conforme mostrado acima.

\subsection{Tipografia}

A tipografia é também um recurso utilizado na linguagem dos quadrinhos, além de dar forma, ela transmite uma mensagem para o leitor. Por exemplo, uma letra tremida pode indicar medo; maiúsculas, gritos; entre outros.

Ainda existem as pictogramas que estão associadas aos ornamentos gráficos e podem ser utilizados como sinalização (figura 16). Elas podem ser utilizadas quando o personagem usa alguma palavra obscena ou mesmo para expressar os seus sentimentos, podendo, inclusive, substituir os balões de fala tradicionais. (MORO, 2016)

Figura 10: Exemplo de pictograma na história em quadrinhos em tira do personagem


Fonte: Disponível na internet: https://www.depoisdosquinze.com/2013/12/17/resenha-seriede-hq-valente/. Acesso em 13 jan. 2021, às 15h55m. 
As histórias em quadrinhos são marcadas por uma linguagem cheia de complexidade e sofisticação, mas ao mesmo tempo sua aparência é simples e direta, capaz de estimular a imaginação do leitor. Na figura 17, pode-se ver um exemplo da tipografia utilizada por Agostini, ainda sem tantas variações como as apresentadas pelas histórias em quadrinhos mais modernas.

\section{Conclusão}

Pelo exposto é possível concluir, segundo o modelo e características adotadas para se denominar uma obra artísitica como arte sequencial, segundo a denominação do mestre Eisner (1989), ou mesmo como uma história em quadrinhos, que Angelo Agostini pode ter publicado a primeira edição em quadrinhos do mundo no Brasil, mais precisamente em 30 de janeiro de 1869 na revista Vida Fluminense, independentemente do primeiro registro internacional ter sido de Outcault com seu Yellow Kid em 1896, pois, neste caso, é dispensável tal registro por se tratar de obras diferentes. Não se está discutindo a autoria de determinada obra ou marca, o que, então sim, utilizaria o PCT (Sistema Internacional de Patentes) para dirimir a dúvida, mas, sim, o primeiro a publicar uma obra em quadrinhos no globo e, neste caso, a nosso ver, não há dúvidas que, com uma vantagem de 27 anos, Agostini, independentemente de sua nacionalidade, o fez primeiramente no Brasil.

Outrossim, ainda que se argumente o uso inventivo dos balões por parte de Oultcault, como já supracitado, estes são plenamente desnecessários para definir uma obra como de histórias em quadrinhos, pois é possível construir uma narrativa gráfica sem o uso de qualquer texto.

Como assevera Cirne (2000, p. 29) "os quadrinhos, como linguagem, têm a sua especificidade, que não reside propriamente no balão... reside, antes, no modo narrativo visual capaz de agenciar elipses gráficas e espaciais."

E, sem dúvida, tal narrativa encontra-se presente na obra protagonizada por Nhô Quim (figura 18). 
Figura 18: Nhô Quim - Modo Narrativo Visual

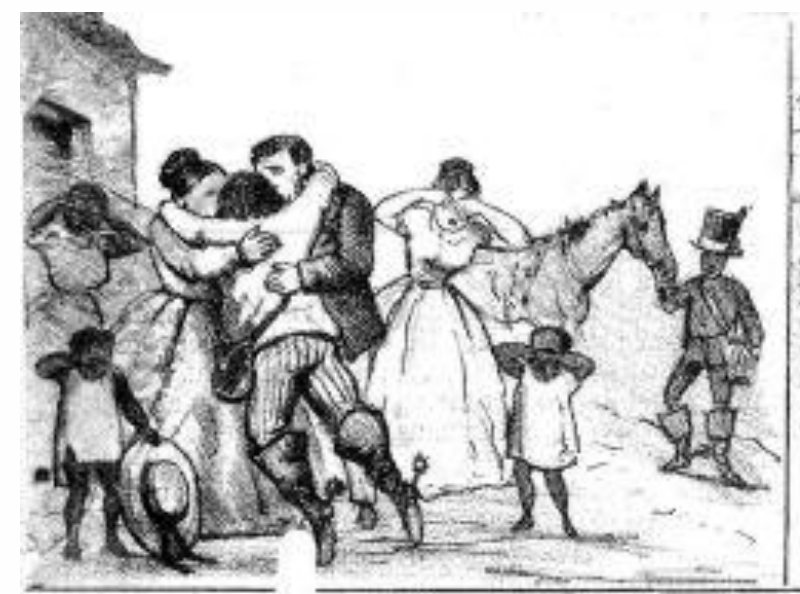

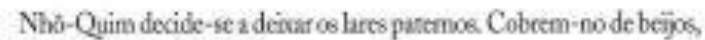
abrapos, conselhos e bệnciod

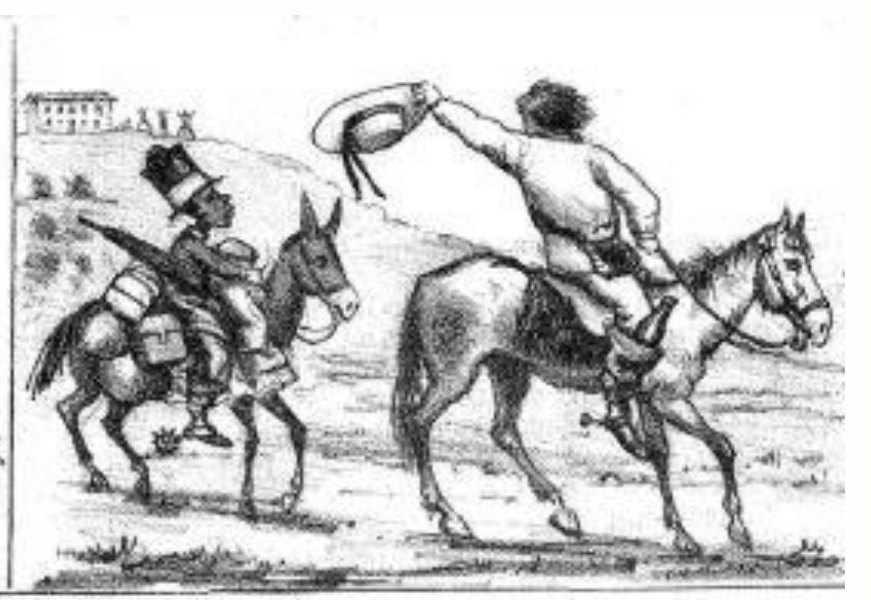

Montado no cavalinho rupo, diz o nosso herói o último adeus!

Fonte: Disponível na internet: $h$ ttp://blogdosquadrinhos.blog.uol.com.br/noticia/arch2009-0101 2009-01-31.html. Acesso em 27 out. 2016, às 15h47m.

Não é intenção do presente texto desmerecer a qualidade e relevância da obra de Outcault com o seu genial Yellow Kid ou qualquer outro que veio contribuir para a evolução da Nona Arte, mas prestigiar com verdade e memória um artista que se não era brasileiro no sangue o era por opção, escolhendo nossa pátria para inovar artisticamente e inaugurar um segmento que serve de paixão a inúmeros leitores, edificando um mercado repleto de diversidade, prenchendo nossas vidas com sonhos, aventuras, humor e olhar crítico sobre o mundo, assim como era nosso saudoso Nhô Quim, com todas as características de uma verdadeira história em quadrinhos.

\section{Referências}

BARI, Valéria Aparecida. O potencial das histórias em quadrinhos na formação de leitores: busca de um contraponto entre os panoramas culturais brasileiro e europeu. Tese. (Doutorado em Ciências da Comunicação) - Escola de Comunicacões e Artes, Universidade de São Paulo, São Paulo, 2008.

BRASIL, Giba Assis. Ensaio: politizando a tecnologia e a feitura do cinema. In: PRETTO, Nelson de Lucca; SILVEIRA, Sérgio Amadeu da. (Org.). Além das redes de colaboração: internet, diversidade cultural e tecnologias do poder. Salvador: EDUFBA, 2008. pp. 85-92. Disponível em:

https://www.google.com/url?sa=t\&rct=j\&q=\&esrc=s\&source=web\&cd=1\&ved=2ahUKEwjni4GxqToAhUalrkGHV0-

DNIQFjAAegQIAhAB\&url=https\%3A\%2F\%2Frepositorio.ufba.br\%2Fri\%2Fbitstream\%2Fufba\%2 F211\%2F4\%2FAlem\%2520das\%2520redes\%2520de\%2520colaboracao.pdf\&usg=AOvVaw3rS ioVeNRB3WHFOCBRRVD. Acesso em 12 abr. 2020. 
CAGNIN, Antônio Luiz. Os quadrinhos. São Paulo: Ática, 1975.

CAGNIN, Antonio L. Abertura. In: CALAZANS, Flavio M. A. (ed.). As histórias em quadrinhos no Brasil: teoria e prática. São Paulo: UNESP, 1997. p. 11.

CALAZANS, Flavio Mário de Alcântara. (ed.). As histórias em quadrinhos no Brasil: teoria e prática. São Paulo: UNESP, 1997.

CIRNE, Moacy. Quadrinhos, sedução e paixão. Petrópolis: Vozes, 2000.

COUPERIE, Pierre. História em quadrinhos e comunicação de massa. São Paulo: MAM Assis Chateaubriand, 1970.

ECO, Umberto. Apocalípticos e Integrados. 6. ed. São Paulo: Perspectiva, 2004.

EISNER, Will. Quadrinhos e arte sequencial. São Paulo: Martins Fontes, 1989.

Narrativas gráficas. São Paulo: Devir, 2005.

Quadrinhos e arte sequencial: princípios e práticas do lendário. 4. ed. São

Paulo: Martins Fontes, 2010.

GOMES, Ângela Maria de Castro. Estado Novo: ambiguidades e heranças do autoritarismo no Brasil. In: ROLLEMBERG, Denise; QUADRAT, Samantha (Org.). $A$ construção social dos regimes autoritários: Brasil e América Latina. Rio de Janeiro: Civilização Brasileira, 2010. v. 1., p. 38-70

LOTUFO, Cesar Augusto; SMARRA, André Luís Soares. Os super-heróis brasileiros que educam por meio dos quadrinhos. In: GOMES, Nataniel dos Santos; ABRÃO, Daniel. (Org.). Grandes poderes trazem grandes responsabilidades: refletindo sobre o uso das histórias em quadrinhos em sala de aula. Curitiba: Appris, 2014, p. 157-176.

MARTINS, Silvane Aparecida Freitas. Histórias em quadrinhos: um convite para a iniciação do leitor. In: SIMPÓSIO CIENTÍFICO-CULTURAL, 1ํ, 2004. Anais. Paraiba: UEMS, 2004.

MCCLOUD, Scott. Desvendando os quadrinhos. São Paulo: Makron Books, 1995.

MORO, Gláucio Henrique Matsushita. Pictograma e pictografia: objeto, representação e conceito. Tese (Doutorado). Universidade Tecnológica Federal do Paraná. Programa de Pós-graduação em Tecnologia, Curitiba, 2016

RAHDE, M. B. Origens e evolução da história em quadrinhos. Revista FAMECOS, Porto Alegre, n. 5, nov. 1996.

RAMOS, Paulo. A leitura dos quadrinhos. São Paulo: Contexto, 2009

SAMARA, Timothy. Elementos do design: guia do estilo gráfico. São Paulo: Editora Bookman, 2010.

SILVA, Marly Custódio. Chico Bento em Pavor Espaciar: uma abordagem sociolinguística da Graphic Novel de Gustavo Duarte. 2015. Monografia (graduação em Letras) - Universidade Estadual do Mato Grosso do Sul, Campo Grande, 2015. 
VERGUEIRO, Waldomiro. Histórias em Quadrinhos: seu papel na indústria de comunicação de massa. Dissertação (Mestrado em Ciências da Comunicação) Escola de Comunicações e Artes, Universidade de São Paulo, São Paulo, 1985.

VERGUEIRO, Waldomiro. Uso das HQs no ensino. In: RAMA, Ângela; VERGUEIRO, Waldomiro. (Org.). Como usar as histórias em quadrinhos na sala de aula. São Paulo: Contexto, 2004.

VERGUEIRO, Waldomiro. A linguagem dos quadrinhos: uma "alfabetização" necessária. In: RAMA, Ângela; VERGUEIRO, Waldomiro. (Orgs.). Como usar as histórias em quadrinhos na sala de aula. 4. ed. São Paulo: Contexto, 2010. 